\title{
JUDICIAL TOLERANCE OF THE INCORPORATED PARTNERSHIP
}

\author{
George D. Hornstern*
}

Variants of the corporate form have vitally affected American life from the very first-even before the moment the Pilgrims set foot on Plymouth Rock. The owner of the lands they had planned to settle was a chartered company, to wit: "The Treasurer and Company of Adventurers and Planters of the City of London for the First Colony in Virginia." The specific voyage was a joint-stock enterprise. And the Mayflower Compact, hastily prepared when the colonists found themselves far north of their expected destination, was designed to provide still another quasi-corporate form without benefit of charter.

Corporation law confirms the eternal legal triangle of statute, common law, and custom; and of these three, as the foregoing illustrations evidence, the most flexible element continues to be custom. ${ }^{1}$ Clearly, the law of corporations never was and is not entirely statutory. In a no-man's land unoccupied by the legislature, the "incorporated partnership," for example, is a reality. Its vitality is conclusively demonstrated by flourishing practices, office files, and judicial opinions. Not the legislature, but the judges (who must deal with lawyers) and the lawyers (who must deal with clients) have quickened into life a type of business organization needed to meet the exigencies of the market place.

Changing views as to the nature of the judicial process itself will continue to affect the courts' acceptance of new business forms. Judges have increasingly recognized that law is a social tool to further, not to thwart, the activities of the individual, the tempo of their acknowledgment being accelerated by Cardozo's writings. Such judicial pioneering is actually the essence of our common law system. Judges do not always wait for statute to sanction practices which business has developed to meet new needs and which, the courts find, harm no one. And although the courts have

- A.B., I924, College of the City of New York; LL.B., 1926, Columbia. Member of the New York bar and an active practitioner; Chairman, Committee on Federal Legislation, New York County Lawyers Association. Columbia University Fellow, 1926-1927. Lecturer on Corporation Law, New York University, teaching graduate courses in Organizing Business Enterprises; Shareholder Control in Corporations; The Close Corporation and Related Problems. Author of Stockholders'Agreements in the Closely Held Corporation, 59 YALE L. J. ro40 (1950); The Future of Corporate Control, 63 HARv. L. Rev. 476 (I950); Corporate Control and Private Property Rules, 92 U. of PA. L. REv. I (r943). Author of numerous other articles extensively cited by the courts.

${ }^{1}$ Contrast the limited operation (prospective only) of statutes with the operation (both retrospective and prospective) of custom and common law. The present writer subscribes to the views of $T$. E. Holland, The Elements of Jurusprudence 60 (13th ed. 1924), that to such customs as come up to a certain standard of general reception and usefulness the courts grant retrospective as well as prospective recognition, implying that the custom was law before it received the stamp of judicial authentication. Contra: John Austin, Lectures on Jurisprudence \$775 (Campbell ed., I875). 
not always been immediately responsive to the customs of the market place, they have not lagged far behind.

The evolutionary character of our common law is especially well illustrated by the incorporated partnership. This adaptability of law to the business environment has been achieved not through some mysterious missing link, but through the art of the counselor, whose skill in the creation of new business forms is as intriguing and socially useful as the work of a naturalist. When from two or more "classic" forms our legal Burbanks evolve a hybrid which is sanctioned by the courts, the product is a new but equally valid species. In law, even unsuccessful efforts help to formulate the outcome. Pioneering must precede the "test" cases which establish the accepted features thereafter to be used with confidence by more conservative members of the profession. For by the very nature of their adaptation to a continously changing business world, business forms are not final but evolutionary.

Upon the classic partnership and the classic corporation modifications have steadily been grafted, until today only those ignorant of actual practices can deny the existence of unincorporated corporations and of incorporated partnerships. Both the partnership and the corporation can be found at least as early as the Middle Ages (and their origins may reach as far back as the partnership of Jacob with Laban, recorded in the Old Testament, or the guild and municipal corporation, so ably depicted by Gross).

In eightenth-century England at a time when royal and parliamentary strife made incorporation too costly, there developed an unincorporated association without benefit of charter-the joint-stock company. Although technically a partnership (the only business form available without governmental grant), it had none of the classic incidents of a partnership. In fact, every partnership incident was reversed except personal liability, and this vestigial characteristic was limited in so far as contractual obligations were involved. The general incorporation laws of the past century originating in the democratic United States were in one sense, as Maitland said, the graceful capitulation of the state to the unincorporated joint-stock company; these laws were also an inevitable step in an evolutionary process.

The notches cut into the classic forms of partnership and corporation largely obliterated the line of demarcation between them. Not very illuminating then is the definition found in the constitutions of almost half our states that the term "corporation" includes any association "having any of the powers or privileges of corporations not possessed by individuals or partnerships." ${ }^{2}$ Yet identification of a business form as partnership or corporation does command more than merely academic interest; it does have pervasive legal consequences.

It may be helpful to restate briefly the well-recognized elements in the older and simpler form, the partnership. Probably its principal characteristic is a negative one-lack of a juristic entity. The affirmative incidents of the partnership are few:

${ }^{2}$ F. J. Stimson, The Law of the Federal and State Constitutions of the United States $\$ 500$ (rgo8). 
The partners as principals own the assets directly; each partner as principal and as agent for his fellow-principals has implied authority to act for all within the scope of the partnership business; and, in the absence of an agreement to the contrary, each partner has a right to take part in the management of the business. By definition, the partnership does not survive the death or withdrawal of a partner.

In the classic partnership these characteristics were reasonable in view of the ensuing legal consequences. Direct ownership results in personal liability; not only the individual's investment but also his personal fortune can be called upon to make good any liabilities incurred within the scope of the partnership business. Since any partner has such unlimited power over the resources of his fellows, there must be complete confidence in all fellow-partners, and new partners cannot be substituted. Also incidental to such extensive power vested in each partner during the life of the partnership is the safeguarding rule that any partner may at any time dissolve the partnership. ${ }^{3}$

Despite the seeming rigidity of these elements in a partnership, one or more may be modified-although if all are changed the business form can no longer be called a partnership. Limited liability through use of a "limited partnership" is by statutory enactment available in every state in this country, as well as in England. Power in the common name to acquire and dispose of property real or personal, to sue and be sued is also accorded to partnerships by statutes in many jurisdictions. By agreement, it is conceded, the parties may even provide that the death of a partner shall not result in winding up, but that the survivors shall have the power to continue the business, albeit-theoretically-as a new partnership. A number of these modifications are found in practice with or without benefit of statute. Other changes have been effected under statutes like the Uniform Partnership Act and the Uniform Limited Partnership Act, which modify the common law conception and give to the partnership certain attributes of a juristic entity. Regardless of variations from the classic form, entity attributes are at times also imposed by regulatory (or exclusion) statutes, common name statutes, tax laws, bankruptcy practices. Illustrative is the equitable doctrine of "marshaling assets," which gives some effect to the entity while ultimately imposing unlimited personal liability on the general partners.

The partnership incidents, if they may still be so called, contrast sharply with the principal characteristic of the corporation-a juristic entity separate and apart from the members of which it is composed. This feature assures the individual participants freedom from liability beyond the avowed investment in the undertaking; the corporate capital stands in lieu of individual liability of the participants. The entity aspect at times also results in a tax saving, although the pendulum-like swings of the tax law often make the business form which was a tax-saver one year costly taxwise in a subsequent year.

\footnotetext{
3 The withdrawing partner, however, will be liable for breach of contract if he lacks legal justification for withdrawal prior to the termination date set in the partnership agreement.
} 
The entity concept of a corporation, however, is no more inviolable than the non-entity concept of a partnership. The courts need not and do not attempt to fit every corporation into a single Procrustean bed. Such action would not be justified by either sound precedent or common sense. The size of the enterprise, the number of participants, the circumstances under which it operates-these characteristics will determine which of several possible concepts shall be employed. The diverse views as to the nature of the business form treat the corporation as: persona ficta, a juristic person, but one lacking elements which an anthropomorphic metaphor is unable to confer upon it; ${ }^{4}$ a reality, almost like a natural person; ${ }^{5}$ an enterprise entity which takes its being from the reality of the underlying enterprise; ${ }^{b}$ or $a s y m b o l$ for an aggregate of men and women and their jural relations.7

Confusion must result when the name "corporation" is applied indiscriminately to a legal form which may have a life shorter than that of the butterfly (of record are corporations formed in a morning for a limited purpose and dissolved the same afternoon after that object had been achieved), as well as to a legal form whose life may be expected to continue as long as our economic system survives; to an enterprise with over a million shareholders as well as to one with but a single shareholder. Is the sole shareholder, moreover, the sovereign government itself, or a legitimate businessman who intends to operate in the corporate form to limit his liability, or a fly-by-night promoter who is cloaking his operations in corporate form to avoid accountability for fraud, i.e., conduct which would be fraudulent were it not in corporate form?" The varied Protean-like forms which the term "corporation" conceals illustrate the consequences which ensue when the metaphor obscures reality, when words intended as an aid to understanding become a substitute for it, when connotations start a chain reaction of new meanings. Called by Littleton and Coke "a body politike" (= framed by policy of the law); said by Marshall ${ }^{10}$ to be an "artificial being, invisible, intangible, and existing only in contemplation of law"; defined thereafter by Angell and Ames" as "an intellectual body" (= perceptible only to the intellect); the ultimate refinement is to be seen in one statute that "corporations are intellectual beings, different and distinct from all the persons who

‘ Case of Sutton's Hospital, ro Co. 23a, 32b, 77 Eng. Rep. 960, 973 (K. B. I612). For an excellent analysis of both the "fiction" and "realist" theories, see Freund, Legal Nature of A Corporation (1896).

ESalomon v. Saloman \& Co., Ltd., [1897] A. C. 22, 33-34. This doctrine, formulated by Gierke in Germany, was sponsored by Pollock in England.

- Berle, Enterprise Entity Theory, 47 CoL. L. REv. 343 (1947).

7 Cardozo, The Growth of the LaW 29-30 (1924); see Farmers' Loan \& Trust Co. v. Picrson, 130 Misc. I10, II9, 222 N. Y. S. 532, 543 (Sup. Ct. I927). Professors Hohfeld, Machen, and Morawetz all favored this concept.

${ }^{8}$ Old Dominion Copper Mining \& Smelting Co. v. Lewisohn, 210 U. S. 206 (xg08). Cf. Old Dominion Copper Mining \& Smelting Co. v. Bigelow, I88 Mass. 315,74 N. E. 653 (1905) (on demurrer), 203 Mass. 159, 89 N. E. I93 (1909) (on merits), aff'd, 225 U. S. II (I912) (holding the earlier decision in 210 U. S. 206 not res judicata as to bind the Massachusetts court).

${ }^{\circ}$ Co. Litt. $250 a$.

${ }^{10}$ Trustees of Dartmouth College v. Woodward, 4 Wheat. 518, 636 (U. S. I819).

$11 \mathrm{~J}$. K. Angeld and Samuel Ames, a Treatise on the Law of Private Corporations Aggregate 21 ( 1832 ). 
compose them."12 Although centuries ago Coke, and still earlier, in 1245, Pope Innocent IV (himself a lawyer) had ruled that the corporation (corpus $=$ body) does not have a soul and cannot be excommunicated, the stage is almost set for revival of the question whether a corporation does have a soul. One modern corporation has actually described itself as "the corporation with a soul."

It is not the object of this writer to enter the lists on behalf of any one of the foregoing concepts to the exclusion of all others. Each of the theories is useful for certain purposes. No theory should be employed, however, which will defeat the public convenience or protect fraud or iniquity or inequity. Even the most ardent advocates of "the fiction theory" would themselves pierce the corporate veil to win their mistress, Justice. ${ }^{13}$

Changing views as to the nature or incidents of a corporation have naturally produced varied legal consequences. Unchanged is the feature that a corporation must have a local habitation and a name in which it can acquire and dispose of property real or personal, enter into other legal relations, sue and be sued. But all other aspects of legal personality have been under pressure. The separate juristic entity has often been ignored by the Supreme Court of the United States, which looked through the corporation to the underlying owners and applied constitutional safeguards to protect their rights. ${ }^{14}$ Where a corporation had been inadequately capitalized, its controlling shareholder has found-although on extremely rare occasions-that limited liability is denied him; ${ }^{15}$ more frequently the entity is disregarded to the extent of subordinating to the claims of outside creditors a claim of the stockholder as a creditor for money allegedly loaned (not contributed as capital) to the enterprise. ${ }^{16}$ For tax purposes also the corporate entity has on occasion been disregarded: at one time to tax the shareholders as if they were partners in the business; ${ }^{17}$ and, conversely, to prevent unjustified taxation, as when it is recognized that common shareholders receiving a stock dividend have really received nothing of value in addition to what they possessed before. ${ }^{18}$

Although the corporation does have some attractive features, especially that of limited liability, the incorporators join together as in a marriage of convenience. For despite the over-all appeal, enterprisers in a small venture dislike at least three

${ }^{12} \mathrm{Ls}$. Clv. CoDE $\$ 435$ (Dart, 1945).

${ }^{13}$ Wormser, Piercing the Veil of Corporate Entity, 12 CoL. L. Rev. 496 (1912). (19I8).

14 Henderson, Position of Foreign Corporations in American Constitutional Law i74, i86

${ }_{16}$ Luckenbach S. S. Co., Inc. v. W. R. Grace \& Co., Inc., 267 Fed. 676, 68I (4th Cir, I920); Oriental Investment Co. v. Barclay, 25 Tex. Civ. App. 543, 559, 64 S. W. 80,88 (Igor); see E. R. LatTy, Subsidiaries and AFfiliated CoMpanies (I936).

${ }_{16}$ Taylor v. Standard Gas \& Electric Co., 306 U. S. 307 (I939) (claim subordinated); Pepper v. Litton, 308 U. S. 295 (I939) (claim disallowed).

${ }^{17}$ Section 117 of an Act to provide Internal Revenue, etc., 13 STAT. 223, 282 (I864), directed that "the gains and profits of all companies, whether incorporated or partnership . . . shall be included in estimating the annual gains, profits or income of any person entitled to the same, whether divided or otherwise." Excepted from this provision and accorded different tax treatment were corporations in specified types of business, e.g., banks, insurance companies, railroads. This Civil War legislation was interpreted and applied in Collector v. Hubbard, 12 Wall. I (U. S. 1870).

${ }^{18}$ Eisner v. Macomber, 252 U. S. 189 (1920). 
attributes of the corporate form: centralized management in a board of directors; free transferability of ownership shares; continuity of organizational life despite the death or withdrawal of a participant. Knowing that these are the usual subjects of controversy, a minority shareholder-to-be is concerned in the first instance about the power of abuse by the directors or majority shareholders. He realizes also that he can get out of the business only by sale of his shares or by the power to compel termination of the venture. By a shareholders' agreement the participants seek to modify or dispense with the unwanted attributes, to anticipate potential sources of dispute on these and other subjects before they arise, and to make provision for their amicable settlement.

What is or should be the public policy with respect to such shareholders' agreements?

It is true that one may raise the important question of how public policy is determined. In one sense, of course, public policy is a matter of adding up individual opinions; for "what one man or one Judge . . . might think against public policy, another might think altogether excellent public policy."10 And however firmly established by judicial opinion may be a conclusion as to public policy, it gives way when the legislature by statute announces a contrary rule. Legislation, however, must be interpreted by the courts. Those which, for example, emphasize the statutory declarations that "the business of a corporation shall be managed by its board of directors," corporation "may contain any provision for the regulation of its business and the conduct of its affairs, and any limitation upon its powers, or upon the rights of its stockholders or upon the power of its directors and members, which does not exempt them from the performance of any obligation or duty imposed by law."21 In at least one state (Ohio) the theory of the general corporation laws is very clearly that a corporation is a contract, precisely as is a partnership.

It is the court which ultimately must determine whether the legislative "policy" can be so-called only in a Pickwickian sense, whether the enactment into "law" of the wishes of a persuasive group concerned with the problems of the large corporation necessitates the frustration of carefully considered agreements by participants in a small venture, also labeled a corporation. Here the court must exercise functions more nearly legislative than judicial. Sometimes judicial interpretation of legislative policy is reversed by the legislature, which then leaves no doubt as to its attitude; witness: New York's recent law validating shareholders' agreements. ${ }^{22}$ In support of such voluntary agreements to avoid dissension, it may be noted further that the law favors the settlement of disputes; that parties may stipulate in an agreement an exclusive form of remedy which the courts will enforce; that parties by

${ }^{10}$ Besant v. Wood, 12 Ch. Div. 605, 620 (1879) (per Jessel, M. R.).

${ }_{20}^{\circ} \mathrm{N}$. Y. Gen. CoRr. LAw $\$ 27$. A comparable provision appears in the statutes of more than threcquarters of the states.

${ }^{21}$ N. Y. GEN. CoRp. LAW $\S_{3}(2)$. Other states have a provision equally broad, e.g., Delaware, Massachusetts.

${ }^{22}$ N. Y. STOck CoRp. Law $\$ 9$. 
stipulation may even waive the right to appeal. It is difficult, therefore, to find any logical reason why legally competent individuals should not be able to adapt a statutory business form to the structure they want, so long as they do not endanger other shareholders, creditors, or the public, or violate an unequivocal mandatory provision of the statutory law.

We thus come to what is interchangeably called a "chartered partnership"23 or an "incorporated partnership," 24 This classification connotes more than the term "close corporation," which has been defined as "a corporation in which the stock is held in few hands, or in few families, and wherein it is not at all, or only rarely, dealt in by buying or selling." 25 The broader term includes also the very important problems of control.

A few-amazingly few -opinions have touched upon the possibility of an outright "incorporated partnership" with stock certificates being issued to "A and B, as partners," instead of to the parties severally. A handful of these opinions have held or suggested that the parties would then be partners inter se while still enjoying the protection of limited liability. ${ }^{26}$ The non-use of this device strongly indicates a professional sense that the practice will not win general judicial sanction.

It is unfortunate but clear that where the shares of stock have been issued to the individual shareholders severally, most courts would presently hold invalid a frank agreement that the corporation shall be operated as a partnership. ${ }^{27}$ Just how far then can participants go to achieve their objective? What do the courts strike down?

\section{Centralized Management}

Courts during the past century have endeavored to maintain the "norm" of centralized management. Their alleged justification was that directors derive their power from the state, not from the shareholders. Behind this bald statement stood the "concession" or "restrictive" theory of corporations which emphasized the high nature of the act of sovereignty by which the corporate franchise is conceded and the extraordinary character of the privileges with which members of a corporation are endowed.

The concession theory, however, has been riddled by reality. What was once a

${ }^{33}$ Bissell v. Michigan Southern \& Northern Indiana R.R., 22 N. Y. 258, 270 (I860).

${ }^{24}$ Cuppy v. Ward, 187 App. Div. 625, 629, 639, I76 N. Y. S. 233, 236, 243 (Ist Dep't I919), aff'd, 227 N. Y. 603,125 N. E. $9 \times 5$ (1919).

${ }^{25}$ Brooks v. Willcuts, 78 F. $2 \mathrm{~d} 270,273$ (8th Cir. 1935). N.B. What we term a "close corporation" the British call a "private company." Their term "close corporation" is confined to what we call a "co-opt."

${ }^{20}$ Smith v. San Francisco \& N. P. Ry., II5 Cal. 584, 601, 47 P. 582, 588 (1897); Arnold v. Maxwell, 223 Mass. 47, III N. E. 687 (IgI6); Seitz v. Michel, I48 Minn. 80, 84, I8I N. W. 102, I04 (I92I); King v. Barnes, 109 N. Y. 267,288 , 16 N. E. 332, 338 ( 1888 ); $c f$. La Varre v. Hall, 42 F. $2 d$ d 65 (5th Cir. 1930).

${ }^{27}$ Jackson v. Hooper, 76 N. J. Eq. 592, 599, 75 Atl. 568, 57 I (Ct. Err. \& App. 1910). Contra: Wabash Ry. v. American Refrigerator Transit Co., 7 F. 2d 335 (8th Cir. 1925), cert. denied, 270 U. S. 643 (1926); Flanagan v. Flanagan, 73 N. Y. S. $2 d 267$ (Sup. Ct. I947), modified, 273 App. Div. 9I8, 77 N. Y. S. 2d 682 (2d Dep't 1948 ), aff'd, 298 N. Y. 787,83 N. E. $2 d 473$ (1949). 
royal grant to a few favored friends has become through democratic incorporation laws the statutory right of all and sundry. Moreover, charter-mongering-eager competition between the states for the business of chartering corporations-has completely undermined the high character of the act of sovereignty. The extraordinary privileges have become ordinary.

Valid throughout the country (except in Louisiana) are one-man corporations, where there can be no denial that the corporation is actually managed by the "one man" shareholder, not by the nominal board of directors. ${ }^{28}$ If two or more shareholders are involved, the public policy so-called invariably permits nullification or modification of corporate incidents when effected through the use of accepted techniques embodied in the articles of incorporation. For example, the principle of majority control in the election of directors may be nullified by giving voting shares to favored participants and non-voting shares to others, or by use of multiple voting shares similarly allocated, or by use of classified shares. Half the states, moreover, expressly authorize voting trusts which bind the owner more effectively than if he had retained the shares under a commitment as to how he would vote. Acceptance of limitations, if a magic form be observed, does not bespeak an enlightened public policy. It confirms rather the belief of many laymen that law is a trap for the unwary.

The theory that the corporation conducts its normal operations only through directors is based upon the unfounded assumption that there is a traditional division of corporate functions. Unfortunately for this theory, some of to-day's so-called norms are the precise reverse of earlier practices, and others at this time are not uniform in all states. Shareholders in the eighteenth century voted directly on certain matters of corporate policy (such as the declaration of dividends) and by vote themselves appointed the executive officers, the latter practice surviving to this day in a dozen states. In England shareholders are regarded as the source of the directors' power; for a score of years England, in fact, did not require a board of directors at all in a "private company," their form of organization which best approximates our close corporation. One of our own states, Iowa, similarly does not require a board of directors. Is it not pointless then to insist upon prerogatives which can at any time be nullified by the shareholders' exercise of their power (unless waived in the articles) to increase the number of directors and to name as new directors men who will be responsive to the shareholders' wishes?

${ }^{28}$ The parallel problems of partnership and corporation are again illustrated when one considers the number of persons who may use one form or the other. The Joint-Stock Companies Act, 1856 , I9 \& 20 Vrex. c. 47 -in a single Act-provided that more than 20 persons could not as a partnership carry on business for profit $(\$ 4)$, and conversely that if the number of shareholders in a corporation fell below 7 , the participants could be deprived of the right to carry on business as a company (\$67). Similar minimal numbers for a corporation were prescribed in a number of our states. Once a minimum number of shareholders for a corporation was abandoned, the next logical stage was the one-man corporation. Today three states (lowa, Michigan, Wisconsin) by statute expressly authorize onc-man incorporation at the outset, and thereby dispense with the "legal form" prescribed in other states, where three "dummy" or "accommodation" incorporators start the corporation functioning and then assign their nominal shares to the real party in interest. 
Another justification advanced was that "the parties cannot be partners as between themselves and a corporation as to the rest of the world." This is mere dogmatic statement, not explanation, for courts which take the opposite position (enforcement of shareholders' agreements) are equally decisive in "explaining" that the parties are "virtually partners." A multitude of situations where, even in the absence of any shareholders' agreement, courts have for certain purposes treated shareholders as partners demonstrate also that there is no inherent objection to this attitude. The famous holding in Eisner v. Macomber that a stock dividend is not taxable income to the shareholder-recipients is based upon the power and duty of the court to look through the corporate form. ${ }^{29}$

The absence of any definitive public policy is apparent in opinions which consider the circumstances under which an agreement was signed, how long it had been in operation without attack upon its validity, whether the person now questioning and endeavoring to repudiate it is in effect "welshing," whether estoppel or a change in position requires its enforcement.

In contrast to early decisions which adjudged void even the simplest shareholders' agreement seeking to modify management by the board of directors, the current case law discloses a tendency to permit some "impingement" upon the principle of centralized management, with the likelihood of judicial sanction increased if all shareholders have signed the agreement. Several modifications are usually attempted: commitment in advance as to the individuals to be chosen directors; change in the bases whereby directors act; control of directors' discretion by having the agreement directly name the officers or fix corporate policies ordinarily determined by directors; superseding of the directors by naming a general manager with powers usually exercised by the board of directors; restrictions on majority rule; grant to the minority of exceptional power to compel dissolution or to prevent it.

The following presentation is a compressed summary of judicial attitude with respect to these attempted modifications. Because of space limitations for this article, all details, qualifications, and exceptions are omitted. ${ }^{30}$

Most courts in the absence of statute will hold invalid a shareholders' agreement (whether in the articles, by-laws, or a separate agreement) requiring unanimity for the election of directors, although an agreement not to vote at all may be valid. Similarly void is an agreement requiring any percentage vote higher than that set by statute, although the result again can be validly achieved-by vote-weighting the shares. Recent legislation in a few states now does permit requirement of a superstatutory majority, even unanimity, if the requirement be set forth in the articles of incorporation.

${ }^{20}$ See note 18 , supra.

${ }^{30}$ Fuller details will appear in the author's forthcoming treatise on Corporation Law and Practice. Sec also Hornstein, Stockholders Agreement in the Closely-Held Corporation, 59 YALE L. J. 1040 (1950); Delaney, The Corporate Director: Can His Hands Be Tied in Advance, 50 CoL. L. Rev. 52 (1950); O'Neal, Restrictions on Transfer of Stock in Closely Held Corporations: Planning and Drafting, 65 HARv. L. Rev. 773 (1952). 
Although in the absence of statute a requirement of unanimity for all action is not generally sanctioned, valid and enforceable everywhere would be an agreement signed by all shareholders to vote their shares as a unit to assure the election as directors of specified persons (usually themselves). In most states the agreement would be enforceable even if some shareholders had not signed.

It is sometimes said that in this country (unlike England) even unanimous vote of the shareholders cannot force a board of directors to act contrary to its judgment and that refusal by the directors would not be cause for their removal. Most scholars discussing what the law should be advocate the contrary position-that a unanimous vote of the shareholders should control or overrule directors. The "law" may be said to be uncertain.

In lieu of attempts to force directors to comply with the unanimous directions of shareholders, some efforts have been made, in the articles, by-laws, or shareholders' agreements, to vary the bases on which directors act. Efforts to require a quorum higher than that prescribed by statute for a directors' meeting have been unsuccessful. Similarly unsuccessful have been provisions that the directors act only by unanimous vote; but occasional cases do sustain the requirement of a voting percentage higher than set by statute provided the percentage be less than unanimity. The shareholders' agreements for control of directors which are most commonly enforced deal with specific items of action ordinarily within the province of the directors, especially as to the appointment and removal of officers and the determination of dividend policy.

In a dozen states, as in England, the statute permits or prescribes that some or all officers be directly elected by the shareholders. In such jurisdictions a shareholders' agreement specifying who shall hold these offices is of course valid, just as is an agreement earlier discussed for election of directors. In most states, however, the corporation statutes require that officers be designated by the directors. In such states, courts have generally sustained composite agreements of all shareholders to elect certain of their number as directors, and then as directors to appoint designated persons (usually the same persons) to particular offices at stated salaries. A few courts have enforced such an agreement even though some of the shareholders were not signatories. Officers ordinarily may be removed not only for cause, but without cause-unless the agreement provides to the contrary. To protect further officers who are minority shareholders, a provision is commonly included that their employment can be terminated only by vote of a specified number of directors.

Although the declaration of dividends is now, as a general principle, within the discretion of the directors, attempts to control the dividend policy have been fairly successful. Probably no court would deny the validity of an agreement which curtails directoral discretion by forbidding the declaration of dividends under specified circumstances. A decision to the contrary would seriously affect billions of dollars of bond indentures already in existence which rely on just that limitation. The converse agreement, providing for compulsory dividends, has also been held 
valid; and, where sufficiently detailed and explicit, has been specifically enforced.

Fear of an independent board of directors and of a majority vote of shareholders which might change the make-up of the board occasionally produces a provision attempting to by-pass the board of directors and strip it of its directoral powers by the appointment of a general manager completely superseding the board. The authorities divide on the validity of such a provision. Factors which influence a court's decision are the length of period for such control and ability to find any of the board's official duties left undelegated. Sharply to be contrasted with the shareholders' displacement of the board by the appointment of a general manager (especially one who is a non-director, an "outsider") is the delegation of the board's powers to an executive committee of one or more of its own members. Such an executive committee is everywhere sanctioned.

Efforts to require unanimity of shareholders have not been confined to the election of directors. Agreements have sought also to make unanimity necessary on other phases of shareholder participation in management, for example, the amendment of by-laws (except where this power is vested in the directors) or the adoption of resolutions at shareholders' meetings. The courts usually uphold a requirement of unanimity for changes in the by-laws or for the adoption of specific shareholders' resolutions, but not for all shareholders' resolutions.

\section{II}

\section{Transferability of Shares}

In marked contrast to judicial resistance to inroads on centralization of management is the court's willingness to permit modification of the second of the so-called norms- "free transferability of ownership shares." The problems anticipated by the parties with respect to transferability are identical with those in a partnership and the proposed solutions, as is to be expected, are parallel. Here we find that the courts have long been sustaining reasonable restraints, much as they would in an ordinary partnership agreement. In fact, the rule in this country ${ }^{31}$ appears to be that shares are freely transferable unless a reasonable restriction on transfer is affirmatively stated. Into the standard of reasonableness three elements enter: the objective, actual or believed; the degree of restraint (or the duration of an absolute restraint) proposed to attain that objective; the source of the restriction -where it appears or when the agreement containing it was first made.

\section{A. Objective}

The objective of a restraint on transfer is material. The state wants corporate enterprises to be successful. Hence the desire to choose one's associates or to restrict shareholdings to current employees (to protect the corporation from disgruntled former employees) has usually been accepted as a legitimate purpose

\footnotetext{
${ }^{31}$ Contrast limitations on transferability imposed by English legislation in a "private" corporation, and by Michigan and Pennsylvania on "partnership associations." The latter bar transfer unless the transferee be acceptable; if he be unacceptable, his interest must be bought out.
} 
and sufficient justification for a reasonable degree of restraint, although supplemental reasons are sometimes assigned. Most courts will go further and sanction a supplemental requirement that the shares offered be made available pro rata to the remaining shareholders, thus maintaining the status quo in control; in a state where the law is doubtful, the same result can be achieved by requiring resale to the corporation itself (if the state is one where the corporation may purchase its own shares). Most valid provisions are actually not restraints at all but simply the first step in a sale, and their objective is to assure a reasonable price by setting up the basis before disputes set in. Improvidence in the contract does not concern the court.

\section{B. Degree of Restraint}

The most important element affecting the validity of a transfer restraint is naturally the degree of restraint or the period of duration for an absolute restraint. One must bear in mind, however, that the reputed norm of free transferability causes any restriction to be strictly construed-in favor of transferability. The most common restriction is a "first option" (or "first right of refusal," as it is sometimes described)-prohibition against sale of the shares to an outsider unless first offered to the corporation or to the remaining shareholders; this first option is sometimes extended to the corporation's directors or officers. Analogous to the first option is the common requirement that a deceased shareholder's estate or a shareholder who ceases to be employed by the corporation must within a specified period offer to sell his shares to the corporation or to the remaining shareholders. A first option is uniformly enforced unless circumscribed by legal limitations other than the doctrine of free transferability. Details for arriving at the purchase price and provisions for its payment, so important to the parties, raise no policy problem for a court.

Other limitations which might result in a permanent restriction, such as a requirement that the directors or other shareholders approve before shares can be transferred, have caused courts to divide sharply. ${ }^{32}$ Restrictions barring transfers to competitors have encountered considerable judicial opposition and are therefore infrequently used. Surprisingly, similar uncertainty prevails with respect to restrictions on sales to aliens. ${ }^{33}$

No time limit is specified ordinarily for the first option to arise, as contrasted with the time within which it must thereafter be exercised, the latter period commonly being set at $3^{\circ}$ days. No time limit is necessary because a "sale" agreement whose restrictions simply impose conditions is not an absolute restraint, although the conditions do make the shares less attractive and lower the value on a sale. In almost all cases where the courts have voided a restraint in the articles or one appearing elsewhere of which notice was adequate, the basis has been that the restraint was absolute by its terms or in effect. The objection is ultimately (not

\footnotetext{
${ }^{32}$ Uniformly, however, courts sanction a provision in corporate-owned co-operative apartment houses that no new shareholder be there recognized without approval of the board of directors.

${ }^{33}$ State statutes may bar shareholding by an alien or may limit land-ownership by the corporation if more than a specified percentage of its shares is held by aliens.
} 
always soundly) based on the Rule against Perpetuities or suspension of the power of alienation or some analogous principle not clearly articulated.

Absolute restraints for a fixed period of time, usually fairly short, have been adjudged valid by a number of courts, with or without express consideration of the problem. In the analogous voting trusts, a maximum, usually ten years, is set by statute. In the absence of statute, draftsmen obviated any question of whether the Rule against Perpetuities applied by limiting the voting trust within the period permitted by that Rule. On the other hand, a recent Delaware decision passing on the validity of a transfer restraint (in a voting trust agreement), set forth its attitude in unmistakable terms: "No agreement would ever constitute a restraint on alienation if we were to give weight to the fact that all parties thereto by unanimous action could always obviate the restraining provision. Yes, we have here a very effective restraint on alienation. ... Any restraint is invalid unless accompanied by circumstances which would justify a reasonable restraint." ${ }^{\text {34 }}$ An equally realistic decision was rendered in Alabama passing on a by-law which barred a shareholder from selling his shares except to other shareholders at book value; the court pointed out that there was no reciprocal obligation on the part of the other shareholders to buy, so that as a practical matter the restraint on alienation was unreasonable. ${ }^{35}$

\section{Source of Restriction}

The source of a restriction-when the agreement is first made or where it appears -is sometimes determinative of its validity. It is not always clear, however, which most influences the court-the timing or the document's standing in the hierarchy of constitutive corporate documents.

Courts tend to sustain a transfer restraint imposed when the corporation is first organized. The explanation sometimes given is that the agreement is part of the conditions under which the corporation was formed and the shares issued-that the privilege of free transferability, for example, is removed before the shares come into existence. But in most instances the nature of the document seems to be determinative, a type of degree of restraint valid in articles of incorporation being ruled invalid in a by-law or mere agreement. Since the provision becomes valid if the articles are amended to include it, not very persuasive is the theory that timing is the important element.

In almost all states unlimited latitude (short of an absolute prohibition on transfer) is permitted for restraints in the articles of incorporation. By-law restraints are not so uniformly sanctioned. Courts refusing enforcement justify their position by explaining that by-laws adoptable by less than unanimous vote cannot be sanctioned as a vehicle for cutting down rights of free transfer usually expected; they argue moreover, that a corporation (whether acting by shareholders or directors) lacks 1949).

${ }^{34}$ Tracey v. Franklin, 6r A. 2d 780, 784-785 (Del. Ch. 1948), aff'd, 67 A. 2d 56 (Del. Sup. Ct.

${ }_{35}$ Security Life \& Acc. Co. v. Carlovitz, 251 Ala. 508, 38 So. 2d 274 (1949). 
authority to curtail "private rights" through by-laws which normally regulate corporate property, not the individual property of the shareholders. Where a restraint is enforced which appears only in a by-law (and as a by-law is invalid), the court usually explains that it is being enforced as an agreement-because agreed to by all the parties at the time the corporation was first organized, or because notation thereof appeared on the stock certificate and therefore was impliedly consented to by the purchaser. Although the articles of incorporation are a matter of public record, the fact that they are not read by investors is recognized by a provision in the Uniform Stock Transfer Act that a restriction cannot be enforced unless noted on the stock certificate. ${ }^{36}$

\section{III}

\section{Permanence}

Continuity of the organization's life despite the withdrawal or death of a participant is the third of the corporate incidents which concerns shareholders or potential shareholders in a corporation. Within recent years legal draftsmen have begun to make provision for compulsory dissolution upon the happening of certain contingencies. Here, the author anticipates, case law will match the liberality sanctioning reasonable restraints on transferability, unlike the conservatism sometimes encountered in attempts to eliminate centralized management. Provisions relating to dissolution may be designed to give a minority which feels oppressed the right to compel dissolution. Or they may have as their purpose the prevention of dissolution where such action would prejudice either the majority or a minority.

Current trends in corporation law recognize the power in a court of equity to decree dissolution in a proper case, even at the suit of a minority shareholder. Can an agreement expand this power of a minority to compel dissolution? Would the courts, for example, enforce a unanimous agreement by the shareholders that the corporation shall be dissolved when one of the parties dies, or enters a competing business, or if dividends have not been declared after the lapse of a specified number of years, or on some other equally foreseeable contingency? The law as to the validity of such a provision is unsettled, condemnation being based on the semantic objection that it attempts to make a "partnership" of a corporation. Can a unanimous agreement expand the power of a $5^{\circ}$ per cent or majority holder to dissolve a corporation, e.g., by negativing in advance any necessity for good faith in exercising his power to dissolve under a statute? We may note here the analogy that when a partnership agreement provides that a majority in interest of the parties may force a minority partner to withdraw, the good faith or motive of the majority may not be questioned.

The converse provision, i.e., to limit dissolution, poses an even more difficult question. The majority or some higher percentage of shareholders usually is

\footnotetext{
${ }^{30}$ Although most states adopted the Uniform Stock Transfer Act verbatim, the section referred to in the text is missing in Kansas and North Dakota, and appears materially changed in California laws. 9 U. L. A. \$15 (Supp. I95I).
} 
granted by statute an apparently absolute right to dissolve; in addition, as above noted, current trends recognize the power in equity to decree dissolution in a proper case, at the suit of majority or minority. The authorities are fairly uniform that the parties by agreement in advance may limit their statutory right to cause dissolution. An agreement can probably require, for example, that parties seeking dissolution show a real difference of opinion as to management or that dissolution would actually benefit all shareholders. Any attempt, however, to limit the court's equitable power invites judicial condemnation. Significantly, an amendment to the New York Stock Corporation Law permitting a requirement of unanimity for all shareholders' action and all directors' actions, specifically states that nothing in the section "shall be construed to limit the power of a court of equity to decree a dissolution in a proper case."37

The subject of dissolution cannot be easily passed over, as it once was, by suggesting that limiting the period of incorporation to a fixed (possibly short) term of years would permit periodic reconsideration of whether its life should be extended. That suggestion had some weight at a time when renewal of a charter required unanimous consent. To-day, however, many states make possible extension of the period of corporate existence, either for an additional term of years or in perpetuity. This may usually be done by a statutory majority, i.e., it may be done over the objection of dissentients. No longer is a limited period for corporate life any assurance to individual shareholders that the corporation will be liquidated at the expiration of that period. ${ }^{38}$ Nor is there presently available to him relief by way of an offsetting statutory right of appraisal-a form of remedy which has been made available to shareholders dissenting from many other types of majority action. ${ }^{39}$

\section{Conclusion}

America is to-day the largest industrial nation committed to a free enterprise economic system. Our economy has been encouraged in large part by the doctrine of limited liability-the opportunity to confine one's risk to his investment. If limited liability be available only to "big business," however, relatively small business is doubly threatened. To the layman and to the lawyer unawed by precedent, the insistence upon unnecessary conditions as the price of limited liability for the small businessman seems unfairly discriminatory, and worse. It is utterly inconsistent with the government's desperate efforts to strengthen the free enterprise system and to alleviate the problems of the small business corporation even at the cost of making tax concessions to it.

A century ago a wise judge pointed out that any corporation is in effect a partnership without personal liability. ${ }^{40}$ The legal craftsmen and later judges have helped confirm his analysis.

\footnotetext{
${ }^{37}$ N. Y. Stock CORP. LAw $\$ 9$.

${ }^{38}$ Garzo v. Maid of the Mist Steamboat Co., 303 N. Y. 516, I04 N. E. 2d 882 (1952).

${ }^{30}$ N. Y. Law Rev, Comm'n, Legis. Doc. No. 65 (I) 390-394 (I943).

${ }^{10}$ Spencer, C. J., in Slee v. Bloom, I9 Johns. 456,473 (N. Y. I822).
} 
It may be expected that with the passage of time more courts will rely less on rigid corporate "norms" and substitute instead frank examination of a questioned agreement to ascertain its purpose and effect, whether its making carries with it any potential danger to the public, to creditors, or to other shareholders. The trend is clear. 